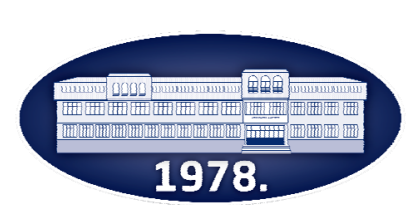

Publisher: Faculty of Agronomy Čačak

\title{
The trends in maize and wheat production in the republic of Serbia
}

\author{
Milosav Grčak ${ }^{1}$, Dragan Grčak ${ }^{1}$, Aleksandra Penjišević2 ${ }^{2}$ Dušan Simjanović ${ }^{3}$, \\ Branka Orbović ${ }^{4}$, Nevena Đukić5 ${ }^{\text {, Vera Rajičić }}{ }^{6}$
}

1University of Priština, Faculty of Agriculture, Kosovska Mitrovica - Lešak, Kopaonička bb, 38219 Lešak, Kosovo and Metohia, Serbia.

2University Union-Nikola Tesla, Faculty of Management, Njegoševa 1a, 21205 Sremski Karlovci, Serbia.

${ }^{3}$ Faculty of Information Technology, Metropolitan University, Tadeuša Košćuška 63, 11000 Belgrade, Serbia.

${ }^{4}$ Institute of Field and Vegetable Crops, Maksima Gorkog 30, 21000 Novi Sad, Serbia.

${ }^{5}$ University of Kragujevac, Faculty of Natural Science, Radoja Domanovića 12, 34000 Kragujevac, Serbia.

${ }^{6}$ University of Niš, Faculty of Agriculture, Kosančićeva 4,37000 Kruševac, Serbia

*Corresponding author: milosavgrcak@gmail.com

Received 30 May 2020; Accepted 14 September 2020

\begin{abstract}
A B S T R A C T
The total area under cereals during 2018 remained at a long-term stable level of about 1.7 million hectares. Maize and wheat are the most important crops grown in the Republic of Serbia. In the structure of harvested areas under cereals, maize dominates (53\%), followed by wheat (38\%). The objective of this paper was to determine if there was a recognisable trend line for the production of these crops in the 2007-2018 period. The yield data (Area harvested (ha), Production (tonnes), Production (t/ha)) were collected from the Statistical Office of the Republic of Serbia. Calculations of relevant and valid trends using central tendency measures, dispersion measures, relative ratios and percentage growth were used for statistical data processing. During the observation period, the average annual growth in maize yield was $6.38 \%$, while the average annual growth in wheat yield was slightly lower, $2.00 \%$. However, it is not possible to create an appropriate trend line for any of the variables in order to predict a future time period, since the coefficient of determination is low.
\end{abstract}

Keywords: maize, wheat, area harvested, production, yield.

\section{И 3 В О д}

Укупна пољопривредна површина под стрним житима у 2018. години није пуно варирала у односу на претходне године и износила је око 1.7 милиона хектара. Кукуруз и пшеница представљају најзначајније биљне културе које се гаје у Републици Србији. У структури пожњевених површина под житарицама кукуруз је доминирао са чак $53 \%$ и био је праћен од стране пшенице са 38\%. Циљ овог рада био је утврдити постоји ли препознатљива линија тренда производње ових култура за период од 2007. до 2018. године. Подаци о приносу (пожњевена површина (ha), производња (у тонама), принос (t/ha)) прикупљени су од Републичког завода за статистику. За статистичку обраду података коришћени су прорачуни релевантних и валидних кретања применом мера централне тенденције, мера дисперзије, релативних показатеља и процентуалног раста. Просечни годишњи раст приноса кукуруза у посматраном периоду износи 6,38\%, док је за пшеницу просечан годишњи раст у посматраном периоду нешто мањи и износи 2,00\%. Међутим, ни за једну од променљивих није могуће направити одговарајућу линију тренда, у циљу предвиђања за будући временски период, јер је коефицијент детерминације мали.

Кључне речи: кукуруз, пшенища, пожњевена површина, производња, принос.

\section{Introduction}

Domestication of crops over a long period has had an enormous impact on the development of human civilization. In order to provide sufficient quantities of organic matter for basic human needs, great attention has been paid to plant production. Through plant production, the required quantities of food are provided for both humans and livestock, and raw materials are secured for the processing industry. However, given the current growth rates of the world population, it is quite certain that, without agricultural intensification, agriculture will need half of the current total land area by 2030, and as much as two-thirds of the current total land area by 2070 to maintain its current level of per capita food consumption (Schneider et al., 2011).

The comparison of crops in the Republic of Serbia shows that wheat and maize are the most commonly grown crops in this country. The total area under cereals during 2018 remained at a long-term stable level of about 1.7 million hectares. In the structure of harvested areas under cereals, maize dominates (53\%), followed by wheat (38\%) (Zelena knjiga 2018 II, accessed on 29th April 2020). These data are not surprising, given that these crops are the most significant in the rest of the world, as well (CruzCárdenas et al., 2019). Wheat (Triticum aestivum) belongs to the order Poales, the family Poaceae (grasses), the subfamily Pooideae (grasses with ears), the genus Triticum. The first classification was given by 
Linnaeus in his work Species plantarum. Wheat, as a bread crop exclusively, accounts for more than $95 \%$ of wheat grown at a global level. Wheat can be classified into vernal (winter) and non-vernal (spring) types based on growth habits and the cold exposure requirement for flowering. Vernal (winter/facultative) wheat accounts for 35\%, while spring (non-vernal) wheat accounts for $65 \%$ of the total bread wheat production (Braun et al., 2010; Braun and Sãulescu, 2002). The pursuit of the best possible yield has led to various studies, and nowadays semi-dwarf genotypes are predominantly grown because they provide an increase in the harvest index of wheat (Knežević et al., 2008; Knežević et al., 2015). Maize (Zea mays) belongs to the order Poales, the family Poaceae (grasses), the subfamily Panicoideae (grasses with ears), the genus Zea. Maize is considered to be one of the first species cultivated by humans as early as 7,000 to 10,000 years ago, as evidenced by maize traces found in caves in Mexico, which are considered to be archaeological sites (Smith, 2001; Piperno and Flannery, 2001 ). Maize contains about $72 \%$ starch, $10 \%$ protein, and $4 \%$ fat, supplying an energy density of $365 \mathrm{Kcal} / 100 \mathrm{~g}$ (Nuss \& Tanumihardjo, 2010). Because of its exceptional nutritional value, maize is one of the most widely grown crops, and it is cultivated at latitudes ranging from the equator to approximately $50^{\circ}$ north and south, at altitudes between sea level and 3,000 $\mathrm{m}$ above sea level (Morris, 2002).

According to the FAOSTAT data for the period 2007-2018, Asia had the highest share in wheat production ( $44 \%$ on average), followed by Europe (33.1\%), and North and South America (16\%). As regards maize, in the same time period, North and South America accounted for the largest share of production $(51.4 \%)$, followed by Asia (30.6\%), and Europe (10.8\%). According to the 2018 data, the People's Republic of China was the leader in wheat production, with a volume of $131,440,500$ tonnes, while the United States of America was the largest maize producer, with a production volume of
$392,450,840$ tonnes (FAOSTAT, accessed 29th April 2020). In the Republic of Serbia, wheat and maize are grown on about 500,000 ha and 1,000,000 ha of land, respectively (Grčak et al., 2018). In 2018, according to the data obtained from the Statistical Office of the Republic of Serbia, the Republic of Serbia produced a total of 2,941,601 tonnes of wheat and 6,964,770 tonnes of maize. The determined characteristics of price fluctuations in the Republic of Serbia indicate an economically optimal time for selling and purchasing wheat and maize. The optimal time for wheat is the period from February to May, while for maize it is July (Mutavdžić et al., 2017b). In Serbia 99.5\% farms are individually owned, and they use $84 \%$ of the total arable land area. The average size of the farms owned by individuals is $4.5 \mathrm{ha}$, and the size varies considerably by region - from 2.1 ha in the Jablanica District to 10.0 ha in the Central Banat District. The remaining $0.5 \%$ of farms are owned by legal entities, and they use $16 \%$ of arable land and have an average size of 210 ha per farm (Strategija poljoprivrede i ruralnog razvoja Republike Srbije, 2014). As reported by Arsić et al. (2015), the share of area under maize in relation to total sown area in the period 2008-2012 was uniform and there was a yield declining trend during the period.

The objective of this paper was to collect basic data on harvested areas (ha), total production (tonnes) and production per unit of measure $(\mathrm{t} / \mathrm{ha})$ in the Republic of Serbia for the period 2007-2018 and to determine the trend line for the production of the crops studied.

\section{Materials and methods}

The data on wheat and maize production in the Republic of Serbia for the period 2007-2018 were analysed using the following variables: Area harvested (ha), Production (tonnes), and Production t/ha. The data collected are presented in Table 1.

Table 1.

Harvested area and total yield of wheat and maize produced in the Republic of Serbia in the period 2007-2018.

\begin{tabular}{|c|c|c|c|c|c|c|}
\hline \multirow{2}{*}{ Year } & \multicolumn{3}{|c|}{ Wheat } & \multicolumn{3}{c|}{ Maize } \\
\cline { 2 - 7 } & $\begin{array}{c}\text { Area harvested } \\
\text { (ha) }\end{array}$ & $\begin{array}{c}\text { Production } \\
\text { (tonnes) }\end{array}$ & t/ha & $\begin{array}{c}\text { Area harvested } \\
\text { (ha) }\end{array}$ & $\begin{array}{c}\text { Production } \\
\text { (tonnes) }\end{array}$ & t/ha \\
\hline 2007 & 625912 & 2342244 & 3.7 & 992941 & 3904825 & 3.9 \\
\hline 2008 & 612256 & 2632091 & 4.3 & 1048815 & 6158122 & 5.9 \\
\hline 2009 & 636434 & 2598182 & 4.1 & 994612 & 6396262 & 6.4 \\
\hline 2010 & 619403 & 2085529 & 3.4 & 1014570 & 7207191 & 7.1 \\
\hline 2011 & 619612 & 2609188 & 4.2 & 1036859 & 6479564 & 6.2 \\
\hline 2012 & 603275 & 2399225 & 4.0 & 976020 & 3532602 & 3.6 \\
\hline 2013 & 631640 & 2690266 & 4.3 & 980334 & 5864419 & 6.0 \\
\hline 2014 & 604748 & 2387202 & 3.9 & 1057877 & 7951583 & 7.5 \\
\hline 2015 & 589922 & 2428203 & 4.1 & 1010227 & 5454841 & 5.4 \\
\hline 2016 & 595118 & 2884537 & 4.8 & 1010097 & 7376738 & 7.3 \\
\hline 2017 & 556115 & 2275623 & 4.1 & 1002319 & 4018370 & 4.0 \\
\hline 2018 & 643083 & 2941601 & 4.6 & 901753 & 6964770 & 7.7 \\
\hline
\end{tabular}

Source: Authors, according to the Statistical Office of the Republic of Serbia, available at

https://data.stat.gov.rs/Home/Result/130102?languageCode=sr-Cyrl, accessed on [4th April 2020]

The data presented in this paper were statistically processed using the SPSS software package (trial version) and the official statistics of the Republic of Serbia in combination with calculations of relevant and valid trends using measures of central tendency, measures of dispersion, relative indicators and percentage growth. Area harvested (ha), Production (tonnes) and Production t/ha were quantitative continuous variables (Hanić \& Šojić, 2008; Mann, 2010). 
The values of the variables Area harvested (ha) wheat, Production (tonnes) -wheat and Production (tonnes) - maize presented in Table 1 show that each variable has a normal arrangement. The value of the variable Area harvested (ha) - maize shows that this variable does not have a normal arrangement.

Area harvested (wheat), Production (maize, wheat):

$$
\begin{aligned}
& \frac{\text { Skewness }}{S E} \in[-1.96 ; 1.96] ; \frac{\text { Kurtosis }}{S E} \in[-1.96 ; 1.96] \\
& \text { Area harvested (maize): } \frac{\text { Kurtosis }}{S E} \notin[-1.96 ; 1.96]
\end{aligned}
$$

\section{Results and discussion}

Based on the data provided in Table 1, the average for Area harvested (ha) - wheat was 611,459.83 ha, the maximum harvested area was 643,083 ha in 2018, while the minimum harvested area was 556,115 ha in 2017. The average for Area harvested (ha) - maize was
$1,002,202$ ha, the maximum harvested area was $1,057,877$ ha in 2014 , while the minimum harvested area was 901,753 ha in 2018.

When it comes to the yield of these cereals in the observation period, the average Production (tonnes) wheat was 2,522,824.25 t, the standard deviation was s $=249,889.38 \mathrm{t}$, with a confidence interval of 95\%, indicating that the average yield was in the interval $(2,364,052.12-2,681,596.38)$, while the average Production (tonnes) - maize was 5,942,440.58 t, standard deviation $\mathrm{s}=1,451,791.21 \mathrm{t}$ and $95 \%$ confidence interval. It is important to note here that the data on both variables, i.e. Production (tonnes) - wheat and Production (tonnes) - maize, were homogeneous, but the coefficient of variation for wheat was 9.91\%, while it was much higher for maize - $24.43 \%$. The frequency polygons showing the Area harvested (ha) for wheat and maize should be symmetrical; however, as illustrated in Graphic1, this is not the case for the whole observation period, except for the last three years.

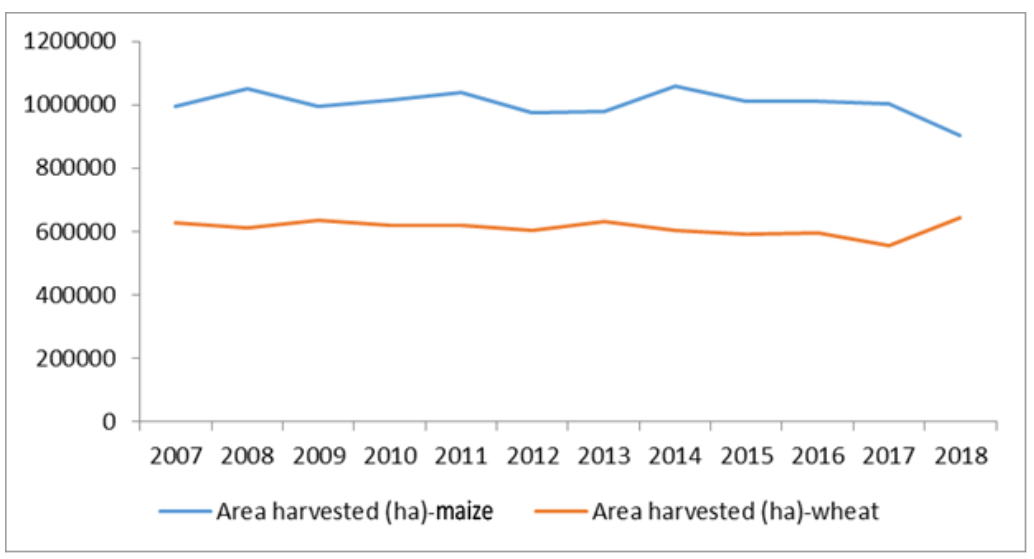

Graphic 1. Area harvested (ha) - wheat and Area harvested (ha) - maize

Source: Authors, according to the Statistical Office of the Republic of Serbia, available at https://data.stat.gov.rs/Home/Result/130102?languageCode=en-Cyrl, accessed on [4th April 2020]

As regards Production $\mathrm{t} / \mathrm{ha}$, we can calculate the $\mathrm{z}$ score for the observation period for wheat and maize. The z-score shows how much a particular datum (single value) deviates from the mean in the number of standard deviations. The z-score sign indicates the direction of deviation (negative means that a specific value is lower than the average), and the calculated number indicates the deviation intensity.

The role of the z-score is to show how much the average values of Production $t /$ ha per year deviate from Production $\mathrm{t} / \mathrm{ha}$ for the entire observation period. The values are given in Table 2 .

Table 2.

Values of the z-score for wheat and maize Production $\mathrm{t} / \mathrm{ha}$

\begin{tabular}{|l|l|l|l|l|l|l|l|l|l|l|l|l|}
\hline Year & 2007 & 2008 & 2009 & 2010 & 2011 & 2012 & 2013 & 2014 & 2015 & 2016 & 2017 & 2018 \\
\hline z-score maize & -1.40 & -0.01 & 0.34 & 0.82 & 0.20 & -1.61 & 0.06 & 1.10 & -0.36 & 0.96 & -1.33 & 1.24 \\
\hline z-score wheat & -1.14 & 0.47 & -0.07 & -1.95 & 0.20 & -0.34 & 0.47 & -0.60 & -0.07 & 1.81 & -0.07 & 1.28 \\
\hline
\end{tabular}

Source: Authors, according to the Statistical Office of the Republic of Serbia, available at

https://data.stat.gov.rs/Home/Result/130102?languageCode=sr-Cyrl, accessed on [4th April 2020]

Table 3 shows that the largest negative deviation of Production t/ha for maize was 1.61 standard deviations in 2012, while the largest positive deviation was 1.24 standard deviations in 2018, indicating that Production $\mathrm{t} /$ ha of maize in 2018 was higher by 1.24 standard deviations than the average for the period 2007-2018. During 2018, weather conditions positively affected maize, unlike in 2017 , which was dry. These conditions contributed to the realisation of a record yield of $7.7 \mathrm{t} / \mathrm{ha}$. This yield was as much as $92 \%$ higher than in the previous year, and $27 \%$ higher than the average of the previous five-year period (Zelena knjiga 2018 II, accessed on 29th April 2020). In wheat, the situation was somewhat worse, the $\mathrm{z}$-score of Production $t /$ ha was negative in 7 years, and the worst situation was in 2010, when Production $t /$ ha was lower by 1.95 standard deviations than the average for the observation period. The best year for wheat was 2016, when the z-score was positive (1.81). In 2016, wheat prices ranged from $15.2 \mathrm{din} / \mathrm{kg}$ to $16.20 \mathrm{din} / \mathrm{kg}$, with 
VAT included, for standard quality delivered to the buyer. The price of wheat in 2015 was $20.13 \mathrm{din} / \mathrm{kg}$ (18.30 excluding VAT) (Produktna berza, 2016). Higher prices of maize relative to those of wheat caused a higher demand for wheat as a substitute for maize for feed production, which could be a possible reason for z-score rating. As shown in Graphic 2, Production t/ha for wheat was quite uniform, while oscillations were observed for maize. This could be attributed to export as a possible reason. Market trends in Serbia indicate that the wheat market is relatively stable, while the maize market is far more volatile because of the impact of export, the most important segment of the demand on the Serbian market (Mutavdžić et al., 2017a).

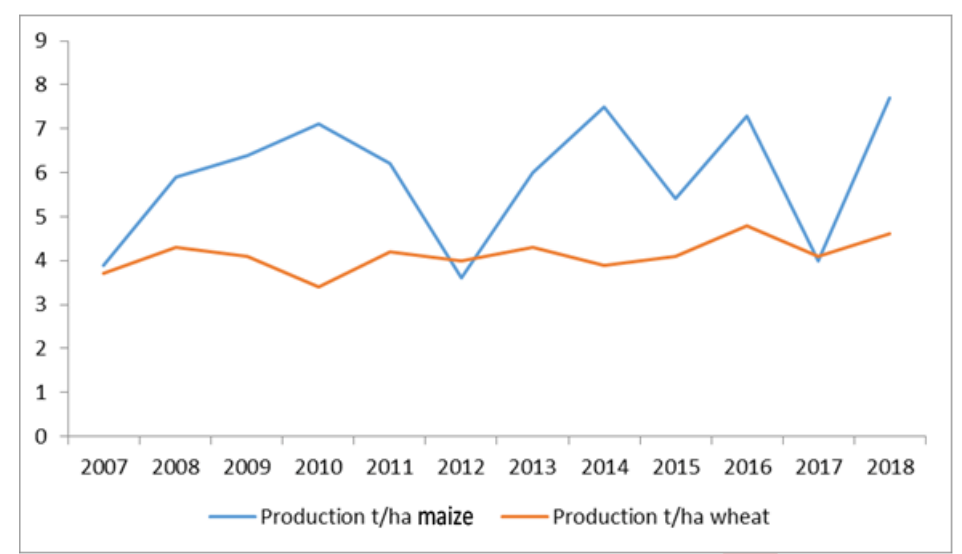

Graphic 2. Production $\mathrm{t} / \mathrm{ha}$ - wheat and Production $\mathrm{t} / \mathrm{ha}$ - maize

Source: Authors, according to the Statistical Office of the Republic of Serbia, available at https://data.stat.gov.rs/Home/Result/130102?languageCode=sr-Cyrl, accessed on [4th April 2020]

Table 3.

Chain indices for sown area and production for wheat and maize in the period 2007-2018 in the Republic of Serbia

\begin{tabular}{|c|c|c|c|c|c|c|}
\hline \multirow{2}{*}{ Year } & \multicolumn{3}{|c|}{ Wheat } & \multicolumn{3}{c|}{ Maize } \\
\cline { 2 - 7 } & $\begin{array}{c}\text { LI for Area } \\
\text { harvested } \\
\text { (ha) }\end{array}$ & $\begin{array}{c}\text { LI for } \\
\text { Production } \\
\text { (tonnes) }\end{array}$ & LI for t/ha & $\begin{array}{c}\text { LI for Area } \\
\text { harvested (ha) }\end{array}$ & $\begin{array}{c}\text { LI for } \\
\text { Production } \\
\text { (tonnes) }\end{array}$ & LI for t/ha \\
\hline 2007 & $/$ & $/$ & $/$ & $/$ & $/$ & $/$ \\
\hline 2008 & 97.82 & 112.37 & 14.88 & 105.63 & 157.71 & 149.30 \\
\hline 2009 & 103.95 & 98.71 & -5.04 & 94.83 & 103.87 & 109.53 \\
\hline 2010 & 97.32 & 80.27 & -17.52 & 102.01 & 112.68 & 110.46 \\
\hline 2011 & 100.03 & 125.11 & 25.07 & 102.20 & 89.90 & 87.97 \\
\hline 2012 & 97.36 & 91.95 & -5.56 & 94.13 & 54.52 & 57.92 \\
\hline 2013 & 104.70 & 112.13 & 7.10 & 100.44 & 166.01 & 165.28 \\
\hline 2014 & 95.74 & 88.73 & -7.32 & 107.91 & 135.59 & 125.65 \\
\hline 2015 & 97.55 & 101.72 & 4.27 & 95.50 & 68.60 & 71.84 \\
\hline 2016 & 100.88 & 118.79 & 17.76 & 99.99 & 135.23 & 135.25 \\
\hline 2017 & 93.45 & 78.89 & -15.58 & 99.23 & 54.47 & 54.90 \\
\hline 2018 & 115.64 & 129.27 & 11.78 & 89.97 & 173.32 & 192.65 \\
\hline
\end{tabular}

Source: Authors, according to the Statistical Office of the Republic of Serbia, available at

https://data.stat.gov.rs/Home/Result/130102?languageCode=sr-Cyrl, accessed on [4th April 2020]

As presented in Table 3, the largest decline in wheat production in $\mathrm{t} /$ ha was $17.52 \%$ in 2010 compared with 2009, while the largest relative growth of $25.07 \%$ was recorded in 2011 compared with 2010. The average growth rate of wheat yield ( $t / h a)$ was $1.84 \%$ per year. As regards the sown area, the only noticeable increase in 2018 compared with 2017 was $15.64 \%$, while the situation for the other years was as follows: the rate of decrease in one year was approximately equal to the rate of increase in the other year. The average annual increase for the whole period was $0.25 \%$. Considering that neither of the trend lines is representative of the movement of yield per hectare of wheat, or more precisely since neither of them shows the observed phenomenon in the right way (the coefficient of determination is close to zero), we cannot determine trends by approximating data from the past. What we can do is to approximate production by the method of moving averages, because it has grouping tendency more pronounced than the tendency of a trend. We will observe the "moving average" with period 3, which represents the average yield in a specific period of time and which is important for us to make a graph that will show us the direction of movement. Like any indicator, these averages will be useful for us to be able to predict future returns. After obtaining the Forecast line, it is possible to create a trend line (Graph 4) and in our case the most representative is the parabolic line, with a coefficient of determination of 0.88 (very representative).

As regards the yield of maize in $\mathrm{t} / \mathrm{ha}$, also, no trend line is representative, and when using the moving average even for period 4 , it is not possible to create a representative trend line for later forecasting.

As for maize, the situation was completely different. The indices of the sown area show that it decreased on average by $0.87 \%$ per year, while the annual yield increased by an average of about $5.40 \%$, and the yield in $\mathrm{t} / \mathrm{ha}$ increased by an average of $6.33 \%$ per year. The largest decrease in yield occurred in 
2017, compared with 2016 , by $45.10 \%$, while the largest increase was in 2018, compared with 2017, by $92.65 \%$.In 2017, compared with 2016, it decreased by only $0.77 \%$. The chain indices of wheat and maize are also presented in Graph 3.

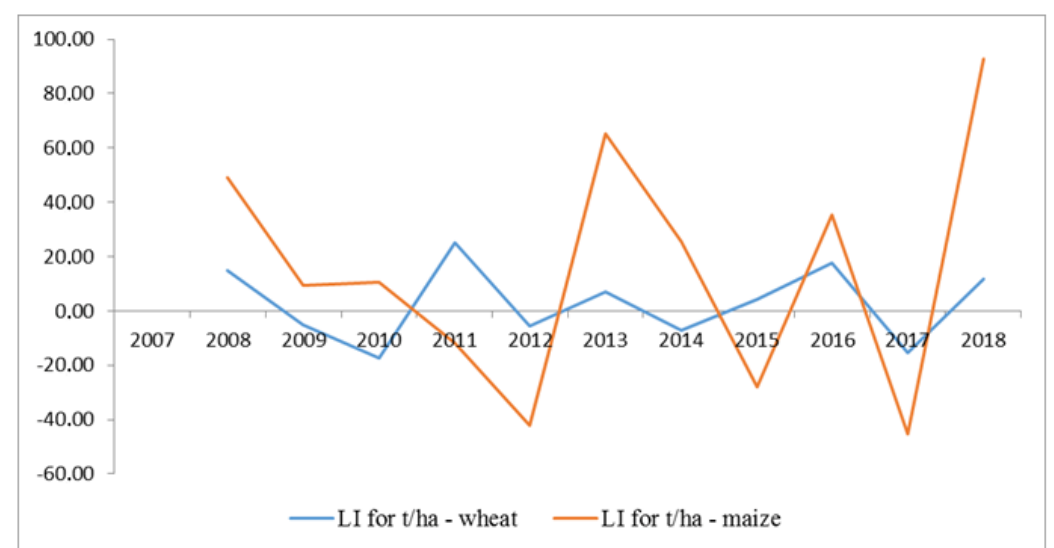

Graphic 3. Chain indices - wheat and maize t/ha in the period 2007-2018 in the Republic of Serbia Source: Authors, according to the Statistical Office of the Republic of Serbia, available at https://data.stat.gov.rs/Home/Result/130102?languageCode=sr-Cyrl, accessed on [4 $4^{\text {th }}$ April 2020]

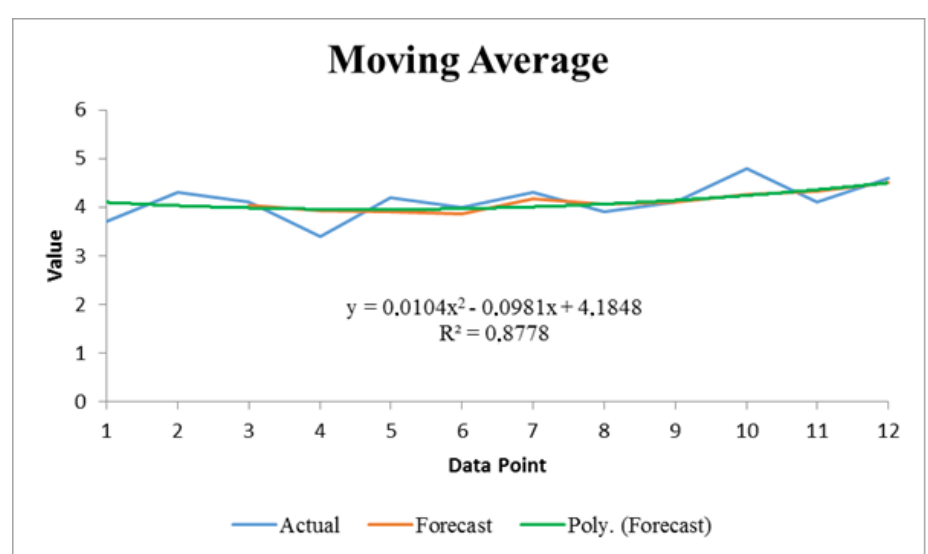

Graphic 4. Moving average - wheat yield (t/ha) in the period 2007-2018 in the Republic of Serbia Source: Authors, according to the Statistical Office of the Republic of Serbia,

available at https://data.stat.gov.rs/Home/Result/130102?languageCode=sr-Cyrl, accessed on [4th April 2020]

Many factors could have caused production fluctuations during the period 2007-2018 and prevented the creation of a representative trend line. Based on literature, one such factor commonly occurring is the influence of weather conditions, because agricultural crop production is closely related to climate (Bursać et al., 2015, Ilić et al., 2016). Yield variations in wheat among years are mainly associated with weather characteristics, especially precipitation and temperature regimes (Marjanović et al., 2010), and it must be noted that weather conditions play a major role in the occurrence of plant diseases. Drought and high air temperatures, in addition to fertile land and hybrid seed, are crucial factors for maize production, which is confirmed by the fact that maize in Serbia is grown under rainfed conditions, indicating that yield is highly dependent on the distribution of rainfall during the growing season (Ranđelović et al., 2010), especially because a very small percentage of areas, only about $3 \%$, is irrigated in Serbia (Serbian Chamber of Commerce, Accessed: 10th August 2020). Based on the tables and graphs presented in this paper, critical years can be detected.

In the period 2008-2012, the share of cereals in the realised value of agricultural production averaged $33 \%$, and ranged from $28 \%$ to $35 \%$. Among cereals, wheat and maize had a high share in the value of agricultural production, which was $6.6 \%$ and $25 \%$, respectively, in the last five-year period before 2013 . In 2013, the share of cereals in the total value of agricultural production was $33 \%$, with maize and wheat accounting for $23 \%$ and $9 \%$, respectively. In the structure of exports in 2013, wheat had the largest share (57\%), in contrast to previous years, when the structure of exports was dominated by maize, with a share of about $86 \%$. The decline in the share of maize in exports was attributed to the fact that the 2012 yield (which was mostly exported in 2013) was extremely low due to drought, as well as due to aflatoxin contamination. As opposed to maize, wheat production in 2013 was extremely high (Zelena knjiga 2013 II, accessed on $5^{\text {th }}$ August 2020).

During 2014, larger areas under wheat were the result of increased export demand for this crop. In 2014, wheat was harvested from about 605 thousand hectares, which gave a total yield of about 2.4 million tons and an average yield of $3.9 \mathrm{t} / \mathrm{ha}$, which was $11.3 \%$ lower than in the previous year. The harvest in 2014 was one of the longest, since it was interrupted by frequent rainfall, which negatively affected the quality and yield of grain. However, favourable weather conditions led to a record maize yield of 7.9 million tonnes that year (Zelena knjiga 2014 II, accessed on $5^{\text {th }}$ August 2020). Due to unfavourable weather, the 
production of maize in 2015 was 5.4 million tonnes, which was $31.4 \%$ lower than the record production, achieved in the previous year, i.e. $12 \%$ below the average of the previous five-year period. The average yield of maize in 2015 was $5.4 \mathrm{t} / \mathrm{ha}$, which was about a third lower than the yield in 2014 (Zelena knjiga 2015 II, accessed on $5^{\text {th }}$ August 2020). During 2016, weather conditions favoured the development of sown maize plants, which yielded $7.3 \mathrm{t} / \mathrm{ha}$. This yield was as much as $35 \%$ higher than in the previous year and $26 \%$ higher than the average of the previous five-year period. In the last ten-year period 2007-2016, the highest wheat yield of $4.8 \mathrm{t} /$ ha was achieved in 2016, which was $17 \%$ higher than both the 2015 yield and the average for the period 2011-2015 (Zelena knjiga 2016 II, accessed on $5^{\text {th }}$ August 2020). Cereal yields in 2017 decreased, compared with the previous year, in the range of $14 \%$ to $45 \%$, depending on crop, due to drought during 2017, which mostly affected the production of maize. This led to a drop in maize yields to an extremely low level of only $4 \mathrm{t} / \mathrm{ha}$. This yield was as much as $45 \%$ lower than the yield in the previous year and a third lower than the average of the previous five-year period (Zelena knjiga 2017 II, accessed on $5^{\text {th }}$ August 2020).

\section{Conclusion}

During the observation period, the average annual growth in maize yield was $6.38 \%$, while the average annual growth in wheat yield was somewhat lower, $2.00 \%$. Regardless of the higher rate of maize yield growth, yield fluctuations are not good from a mathematical standpoint and their causes need to be researched.

It is not possible to make a trend line for any of the variables (Production t/ha - wheat and Production $\mathrm{t} / \mathrm{ha}$ - maize) in order to predict a future period, since the coefficient of determination for the lines is low; therefore, neither of the lines is representative, i.e. neither of them portrays the phenomenon in the "right way." Agriculture is conditioned by many factors, as most of the production is practised under uncontrolled conditions. Based on the literature used, weather conditions and market may be the main reasons for these fluctuations, but further research is needed to determine all underlying factors.

\section{References}

Arsić, S., Kljajić, N., \& Jovanović, M. (2015). Utilization of an agricultural land as a basic capacity for corn and wheat production in Serbia and Ex-Yu countries. Ekonomika, 61(2), 103-116.

Braun, HJ, Atlin, G, Payne, T. (2010). Multi-location testing as a tool to identify plant response to global climate change. In: Reynolds MP, editor. Climate change and crop production. Wallingford (UK): CABI Publishers.

Braun, HJ, Sãulescu, NN. (2002). Breeding winter and facultative wheat. Rome (Italy): FAO; 2002. (FAO Plant Production and Protection Series).

Bursać, M.N., Ivanović, R., Nikolić, M. (2015). Agricultural production in the Niš valley - agroclimatic conditions, Teme, no. 1, pp. 275-289 (available at: http://teme2. junis.ni.ac.rs/index.php/TEME/article/view/2/34)

Cruz-Cárdenas, C.I., Cortés-Cruz, M., Gardner, C.A., Costich, D.E. (2019). Wild Relatives of Maize. In: Greene S., Williams K., Khoury C., Kantar M., Marek L. (eds) North American Crop Wild Relatives, Volume 2. Springer, Cham.
FAOSTAT (Food and Agriculture Organization of the United Nations). http://www.fao.org/faostat/en/e (Accessed: 29th April 2020)

Grčak, M., Grčak, D., Grčak, D., Aksić, M., Đekić, V., Aksić, M. (2018): Comparison of Maize and Wheat Production in Serbia during the 2007-2016 Period. Agro-knowledge Journal, 19(3), 199-210.

Hanić, H., Šojić, M. (2008). Finansijska statistika, Beogradska bankarska akademija, Beograd.

Ilić, I., Jovanović, S., Janković Milić, V. (2016). Forecasting Corn Production In Serbia Using Arima Model. Economics of Agriculture, (63) 4: 1141-1156

Knežević, D., Djukić, N., Paunović, A., Madić, M. (2008). Variability of harvest index and yield components in wheat (Triticum aestivum L.). Cereal Research Communication, 36, 1151-1154.

Knežević, D., Kondić, D., Srdić, S., Paunović, A., Madić, M. (2015). Harvest index and components of yield in winter wheat cultivars (Triticum aestivum L.). Proceeding of Sixth International Scientific Symposium "Agrosym Jahorina 2015" (Editor-in-Chief: Dusan Kovacevic) October 15-18 2015, Jahorina Bosnia and Herzegovina, 368-372.

Mann, P. (2010). Uvod u statistiku, Za izdanje na srpskom jeziku Centar za izdavačku delatnost Ekonomskog fakulteta u Beogradu, Beograd

Marjanović, M., Markulj, A., Tkalec, M., Jozić, A., Kovačević, V. (2010). Impact of Precipitation and Temperature on Wheat (Triticum Aestivum L.) Yields in Eastern Croatia. Acta Agriculturae Serbica, Vol. XV, 30 (2010) 117-123

Morris, M. L. (2002): Impacts of International Maize Breeding Research in Developing Countries, 1966-1998. Mexico, D.F.: CIMMYT.

Mutavdžić B., Drinić Lj., Novaković , T., Vaško Ž., Novković, N. (2017a). The Comparative Analysis of Grain Prices in Serbia and Republic of Srpska, Book of Abstracts, 6th International Symposium on Agricultural Sciences, University of Banja Luka, February 27 March 2, 2017 Banja Luka, Bosnia and Herzegovina, p. 54

Mutavdžić, B., Novaković, N., Vukelić, N., Novaković, T. (2017b): Monthly fluctuations in the prices of grain in Serbia. Journal on Processing and Energy in Agriculture, 21(3), 181-184.

Nuss, E.T., Tanumihardjo, S.A. (2010). Maize: a paramount staple crop in the context of global nutrition. Comprenhsive Reviews in Food Science and Food Safety 9, 417-436.

Piperno, D.R., K.V. Flannery. (2001). The earliest archaeological maize (Zea mays L.) from highland Mexico: new accelerator mass spectrometry dates and their implications. Proc. Natl. Acad. Sci. U. S. A. 98, 2101-2103.

Produktna berza Novi Sad (2016). available at: http://www.proberza.co.rs/27-06-01-07-2016/ (Accessed: 29th April 2020)

Ranđelović, V., Prodanović, S., Despotović, S., Glamočlija Đ. (2010). Prinos kukuruza različitih FAO grupa zrenja u funkciji padavina tokom ASI perioda, Zbornik radova XXIV savetovanja agronoma, veterinara i tehnologa. Beograd, 16( 1-2), 103-111.

Schneider, U. A., Havlík, P., Schmid, E., Valin, H., Mosnier, A., Obersteiner, M., Fritz, S. (2011). Impacts of population growth, economic development, and technical change on global food production and consumption. Agricultural Systems, 104(2), 204-215.

Serbian Chamber of Commerce http://www.pks.rs/PrivredaSrbije.aspx id=13 (Accessed: 10th August 2020)

Smith, B.D. (2001). Documenting plant domestication: the consilience of biological and archaeological approaches. Proceedings of National Academy of Science of the U. S. A. 98, 1324-1326.

Statistical Office of the Republic of Serbia, https://data.stat.gov.rs/Home/Result/130102?language Code=sr-Cyrl, (Accessed: 4th April 2020)

Strategija poljoprivrede i ruralnog razvoja Republike Srbije za period 2014-2024. godine ("Sl. glasnik RS", br. 85/2014), available 
http://uap.gov.rs/wpcontent/themes/uap/STRATEGIJA $\% 202014-2020 \% 20$.pdf

Zelena knjiga 2013 II: http://www.minpolj.gov.rs/korisnadokumenta-i-linkovi/ (Accessed: 5th August 2020)

Zelena knjiga 2014 II: http://www.minpolj.gov.rs/korisnadokumenta-i-linkovi/ (Accessed: 5th August 2020)

Zelena knjiga 2015 II: http://www.minpolj.gov.rs/korisnadokumenta-i-linkovi/ (Accessed: 5th August 2020)

(Accessed: 29th April 2020)
Zelena knjiga 2016 II: http://www.minpolj.gov.rs/korisnadokumenta-i-linkovi/ (Accessed: 5th August 2020)

Zelena knjiga 2017 II: http://www.minpolj.gov.rs/korisnadokumenta-i-linkovi/ (Accessed: 5th August 2020)

Zelena knjiga 2018 II: http://www.minpolj.gov.rs/korisnadokumenta-i-linkovi/ 